\title{
Oxytocin: A Potential Therapeutic for Obesity
}

\author{
Soo Min Hong', Jeong-Kyung Ko², Jung-Joon Moon ${ }^{3}$, Youl-Ri Kim²,4,* \\ ${ }^{1}$ Department of Endocrinology and Metabolism, Seoul Paik Hospital, Inje University, Seoul; ${ }^{2}$ Institute of Eating Disorders and Mental Health, Inje University, Seoul; \\ ${ }^{3}$ Department of Psychiatry, Busan Paik Hospital, Inje University, Busan; ${ }^{4}$ Department of Psychiatry, Seoul Paik Hospital, Inje University, Seoul, Korea
}

Oxytocin is a neuropeptide involved in the homeostasis of food consumption and energy; it affects hedonic eating. Studies in obese or binge-eating patients reported the hypophagic effect of oxytocin, which reduced caloric intake after administration. Several studies have demonstrated the effect of oxytocin's increasing energy intake, decreasing food consumption, and contributing to weight loss. Oxytocin's effects on food intake and metabolism suggest its therapeutic potential for treating obesity and binge eating.

Key words: Oxytocin, Therapeutics, Obesity

\author{
Received September 23, 2020 \\ Reviewed January 8, 2021 \\ Accepted January 21, 2021 \\ *Corresponding author \\ Youl-Ri Kim \\ https://orcid.org/0000-0002-5538-7180 \\ Department of Psychiatry, Seoul Paik \\ Hospital, Inje University, \\ 9 Mareunnae-ro, Jung-gu, \\ Seoul 04551, Korea \\ Tel: +82-2-2270-0063 \\ Fax: +82-2-2275-8818 \\ E-mail:youlri.kim@paik.ac.kr
}

\section{INTRODUCTION}

Oxytocin is a hormone produced in the hypothalamus and secreted by the posterior pituitary gland. ${ }^{1}$ The hormone is involved in childbirth and breastfeeding and affects emotions such as love and affection, social behavior, and metabolic processes. ${ }^{2}$ Several studies have demonstrated the effects of oxytocin on increasing energy consumption and decreasing food consumption, leading to weight loss. Oxytocin's effects on food intake and metabolism suggest its potential for treating obesity and binge-eating.

\section{PHYSIOLOGICAL PROPERTIES OF OXYTOCIN}

Oxytocin is a peptide comprising nine amino acids produced in the brain and peripheral organs. It binds to the oxytocin receptor, which is a member of the G protein-coupled receptor (GPCR) family. ${ }^{3}$ Oxytocin is synthesized in the supraoptic nucleus and paraventricular nucleus (PVN) of the hypothalamus. ${ }^{46}$ It regulates eating behaviors and the metabolism. ${ }^{1}$ Magnocellular neuroendocrine neurons in two nuclei extend axonal connections into the posterior pituitary gland. The hormone is secreted into the peripheral blood circulation ${ }^{7}$ and does not cross back through the blood-brain barrier. ${ }^{8-12}$ Other axonal connections exist between the PVN oxytocin neurons and regions of the brain. The PVN contains parvocellular oxytocin neurons, which protrude into the central nervous system structures including the brainstem and spinal cord. ${ }^{13}$ Parvocellular oxytocin neurons in the PVN connect to the nuclear bed of the stria terminalis, the ventral tegmental area, and the nucleus accumbens and are involved in reward behavior and eating behavior regulation. ${ }^{14-18}$ GPCRs bound by oxytocin are expressed throughout the brain ${ }^{19}$ in structures such as the olfactory nucleus, hypothalamus, amygdala, and anterior cingulate cortex limbic system. ${ }^{20} \mathrm{Oxy}$ tocin interacts with other neurotransmitters, and serotonin has 
been reported to increase oxytocin concentrations. ${ }^{3}$ Dopamine interacts with oxytocin to regulate the activity of the reward circuitry in the brain (Fig. 1). ${ }^{21,22}$ Oxytocin is synthesized in such organs as the placenta, heart, kidneys, uterus, ovaries, testis, blood vessels, and skin. ${ }^{19,23}$ Oxytocin receptors are present on myoepithelial cells, the pancreas, heart, blood vessels, kidneys, thymus, adipocytes, and macrophages. ${ }^{24,25}$ Oxytocin receptors are involved in nitric oxide production, uterine contractions, and lipolysis through $\mathrm{G}$ protein coupling and C-beta pathway activation. ${ }^{26-29}$ The production and secretion of oxytocin in the gastrointestinal tract ${ }^{7}$ are associated

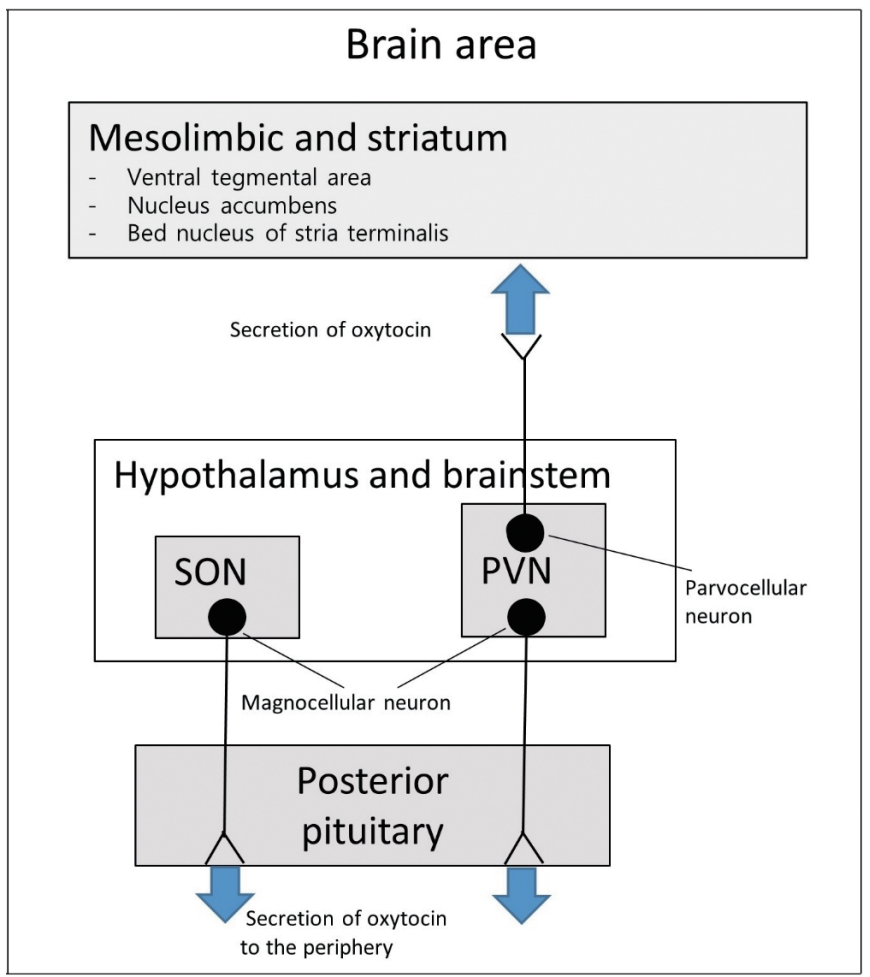

Figure 1. Oxytocin production and secretion in the central nervous system. SON, supraoptic nucleus; PVN, paraventricular nucleus. with autocrine and paracrine effects. ${ }^{30,31}$ Positive feedback effects have been reported from the central or peripheral administration of oxytocin, stimulating auto-receptors in the magnocellular supraoptic neurons. ${ }^{32,33}$ Oxytocin receptors are found throughout the central nervous system and peripheral regions, providing a clue for the regulation of food consumption and metabolism. In addition to the anterior pituitary gland, oxytocin receptors have been observed in the pancreas, adipocytes, and gastrointestinal tract, and studies have reported their association with eating behaviors (Fig. 2). 19,30,34-43

\section{REGULATION OF ENERGY BALANCE AND METABOLISM OF OXYTOCIN}

Oxytocin affects appetite by decreasing intake and promoting lipolysis and the oxidation of fats. It also lowers body temperature and visceral fat while increasing thermoregulation and energy consumption. Furthermore, it plays a role in glucose and metabolic homeostasis, improving insulin sensitivity. ${ }^{1,44}$ An increase in oxytocin sends signals to reduce calorie consumption and raise energy intake. Dysfunction in oxytocin signaling can cause weight gain. Variations in the oxytocin receptor gene have been linked to obesity. ${ }^{45}$ Oxytocin decreases food intake by affecting feeding behavior and causes satiety signaling in the brain. A positive relationship was found between oxytocin levels and body mass index, ${ }^{46}$ and oxytocin levels correlate with visceral fat mass. In addition, a positive association was demonstrated between oxytocin levels and obesity and metabolic syndrome. ${ }^{47,48}$ Oxytocin has been shown to decrease weight and body fat via fat oxidation and lipolysis independent of its effects on food intake. ${ }^{11,33,49,50}$ Decreases in visceral fat and liver fat related to oxytocin ${ }^{49}$ are particularly noteworthy because they are metabolically important fat types associated with a higher risk

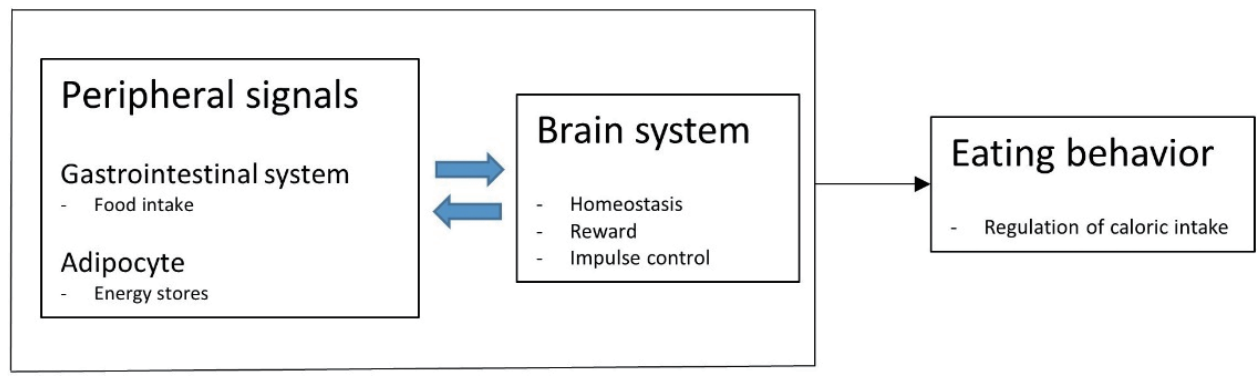

Figure 2. The effect of oxytocin on eating behavior and metabolism. 
of cardiovascular disease and metabolic syndrome. ${ }^{51}$

Oxytocin receptors bind $\mathrm{G}$ protein activated adenylate cyclase to increase cyclic adenosine monophosphate production, resulting in lipolysis. ${ }^{26,28,52}$ The mechanism of energy expenditure facilitated by oxytocin has not been established. However, oxytocin generates thermogenesis by activating brown fat and converting white adipose tissue to beige fat. ${ }^{53}$ Unlike a single dose of oxytocin, chronic oxytocin exposure has been shown to affect energy consumption. ${ }^{54}$ Oxytocin affects metabolism directly and also down-regulates the hypothalamic-pituitary-adrenal axis. Oxytocin was reported to decrease adrenocorticotropic hormone and cortisol release from the anterior pituitary gland and adrenal glands through oxytocin receptors, mitigating the negative metabolic effects of cortisol. ${ }^{43,55-60}$

Oxytocin receptors are also found on pancreatic $\alpha$ and $\beta$ islet cells. ${ }^{42}$ Conflicting responses of oxytocin to insulin and blood glucose have been reported in human studies. Oxytocin caused different effects depending upon the dose or route of administration such as whether the injections were intravenous or intranasal and whether they were delivered in a bolus or by continuous infusion. One study showed a sharp drop in postprandial 3-hour blood sugar following the administration of an intravenous bolus of $10 \mathrm{MIU} / \mathrm{kg}$ oxytocin to postpartum women. ${ }^{61}$

In another study, $10 \mathrm{IU}$ of oxytocin was administered to postpartum women intravenously, but there was no change in blood glucose or insulin levels. ${ }^{62}$ In men, 6 IU of oxytocin, but not 3 IU, increased insulin levels with no change in blood glucose, glucagon, growth hormone, or cortisol levels. ${ }^{63}$ In another study, healthy men in their 20 s were administered oxytocin at $0.2 \mathrm{IU} / \mathrm{min}$ over 60 minutes in a continuous intravenous infusion, which caused hyperglycemia; elevated insulin, glucagon, and adrenaline levels; and decreased cortisol levels. The same results were seen in insulin-induced hypoglycemia. ${ }^{64}$ This suggests that oxytocin affects glucose homeostasis but does not consistently raise or lower blood glucose. Oxytocin improved pancreatic $\beta$ cell responsiveness and insulin sensitivity to a glucose challenge. ${ }^{65}$

Diabetic patients showed high blood glucose, insulin, and glycosylated hemoglobin levels and a high homeostatic model assessment of insulin resistance with low levels of oxytocin. ${ }^{66,67}$ Oxytocin administration increased the expression of glucose transporter type 4 , an insulin-dependent glucose transporter. ${ }^{68}$ Oxytocin directly fa- cilitated insulin secretion from $\beta$ cells of the pancreas through the turnover of phosphoinositide and the activation of protein kinase $\mathrm{C}$, and by indirectly affecting vagal cholinergic neurons. ${ }^{69,70}$

\section{STUDIES ON THE ROLE OF OXYTOCIN IN EATING BEHAVIORS}

Many studies have investigated the impact of oxytocin on the eating habits of rats. Oxytocin suppressed the appetites of mice for sugar and carbohydrates rather than for fat. Oxytocin receptorknockout mice consumed more sweet solutions, sweetened food, and carbohydrates than wild-type mice $\mathrm{e}^{71-73}$ and progressed to lateonset obesity. ${ }^{74}$ Wild-type mice injected with an oxytocin receptor antagonist consumed more sucrose than fat. ${ }^{75}$ Oxytocin expression was reduced in rats with long-term exposure to sugar. ${ }^{76}$ Singleminded 1 gene deletions ${ }^{77}$ and the loss of hypothalamic oxytocin neurons, ${ }^{78}$ which control appetite and weight, have been associated with obesity. Diet-induced obese mice showed dysfunctions in their oxytocin systems. ${ }^{79}$

Injections of oxytocin decreased the feeding and drinking of rats of both sexes in a dose-dependent manner. ${ }^{80}$ Oxytocin administration resulted in greater reductions in food intake in obese rats than in slim rats. ${ }^{81}$ Intraventricular injections demonstrated better effects on the regulation of food consumption than did intraperitoneal injections. ${ }^{82}$ However, peripheral oxytocin administration also improved obesity by decreasing food consumption and visceral fat. ${ }^{49}$ Maejima et al. ${ }^{49}$ showed that both intraperitoneal and subcutaneous (SC) oxytocin injections decreased food consumption and the effects were better in obese mice than in normal-weight mice. Daily SC oxytocin injections decreased food intake and body weight. Chronic oxytocin injections delivered via a pump decreased food consumption, total body weight, and visceral fat. There was no rebound weight recovery. Chronic oxytocin infusions promoted fat usage and improved glucose tolerance. ${ }^{49}$ However, discrepant results of oxytocin effects have been reported.

A meta-analysis by Leslie et al.$^{83}$ reported different results according to sex and the oxytocin administration period. Oxytocin decreased food consumption more in male rats than in female rats, with food intake decreasing over time. A short-term oxytocin treatment delivered as a single dose either by a central or peripheral 
route reduced food consumption, whereas chronic, long-term administration did not. ${ }^{83}$ Altirriba et al. ${ }^{39}$ reported the dose-dependent effects of oxytocin on 1-week reductions in weight and food consumption in obese, diabetic mice. Oxytocin had a smaller effect in thin rats. After 2 weeks, weight gain in the oxytocin-administered group and the saline-administered group was similar. In the higher oxytocin receptor specificity group, the short-term administration of oxytocin produced a small weight gain without any change in food consumption. This suggests that the effect of oxytocin on weight loss was due to decreased food intake as well as increased fat metabolism. ${ }^{39}$

The mechanism by which oxytocin reduces food intake has not been established. However, one hypothesized mechanism of the effects of oxytocin on caloric intake involves the action of oxytocin on homeostatic, reward, and impulse control brain circuitry, which could reduce calorie consumption, particularly of more appetizing foods in response to peripheral signals indicating energy availability. ${ }^{1}$

Several studies on oxytocin and obesity in humans have been conducted. An association between variants of the oxytocin receptor gene, which encodes GPCRs, and childhood obesity was reported. ${ }^{45}$ Single-minded 1 gene variants are also associated with obesity in humans. ${ }^{84,85}$ Reduced numbers and sizes of PVN oxytocin neurons have been reported in Prader-Willi syndrome patients. $^{86}$

One study observed changes on functional magnetic resonance imaging after intranasal administration of 24 IU of oxytocin in 15 normal-weight men. Activity in the ventrolateral prefrontal cortices, ventromedial prefrontal cortex, anterior cingulate, and supplementary motor area increased when the subjects were viewed food images after oxytocin administration. ${ }^{87}$

A randomized controlled trial was performed in Korean women by treating anorexia nervosa, bulimia nervosa, and control groups with $40 \mathrm{IU}$ of intranasal oxytocin. ${ }^{88}$ The administration of oxytocin reduced 24-hour caloric intake in patients with bulimia nervosa. However, intake by women in the anorexia nervosa or control groups was not changed. ${ }^{88}$ Studies have also looked at the central oxytocin effect produced by the administration of 24 IU of intranasal oxytocin in men. In one study, total calorie and fat consumption but not carbohydrates or protein were decreased when oxytocin was administered to 25 men. ${ }^{54}$ In another study, total caloric intake was not decreased after oxytocin was administered in 20 men, but chocolate cookie consumption was reduced by $25 \%{ }^{89}$ In another study, the administration of oxytocin in normal-weight men (20 men) and obese men (18 men) reduced snack consumption. However, the total amount of food consumed was reduced only in obese men. ${ }^{90}$

Single-dose administration of oxytocin showed calorie and weight loss effects, and some studies analyzed the results of chronic oxytocin administration. In a study where 24 IU of oxytocin was administered intranasally four times a day for eight weeks, the participants lost an average of $4.6 \mathrm{~kg}$ after four weeks and an average of $8.9 \mathrm{~kg}$ after eight weeks. More weight was lost by the more obese participants. ${ }^{91}$ A meta-analysis ${ }^{83}$ reported greater decreases in food consumption because of oxytocin in males compared to females, in the satiated state compared to the fasting state, and in more obese subjects compared to less. ${ }^{83}$

\section{THERAPEUTIC POTENTIAL OF OXYTOCIN IN TREATING OBESITY}

In previous studies, ${ }^{54,89}$ intranasal treatment with oxytocin reduced the intake of tasty food such as those high in fats and carbohydrates, resulting in weight loss. Oxytocin decreased food intake by controlling compensatory hedonic eating. ${ }^{92}$ Oxytocin's inhibition of reward-related food motivation ${ }^{1}$ was associated with satiety signals and inhibited activity of the food-related reward pathway. ${ }^{15}$

More research is needed before oxytocin can be used to treat obesity. Studies investigating the side effects of oxytocin in humans reported that intranasal oxytocin administration (1) resulted in no detectable subjective changes in the recipients, (2) caused no consistent side effects, and (3) was not associated with adverse outcomes when given short term in doses of 18-40 IU in controlled research settings. ${ }^{93}$ Oxytocin can modify the heart rate and cause cardiovascular effects, ${ }^{94,95}$ and people with heart and cardiovascular conditions may be more vulnerable to these effects. Susceptible subjects should be selected with consideration of dose and route, treatment effects, and side effects. Nonetheless, we found that oxytocin had beneficial effects, inducing early satiation, reducing reward-driven food intake, ${ }^{89}$ and improving glucose homeostasis. Pharmacological studies should be conducted to develop strategies 
for using oxytocin as a new obesity treatment. Integrated behavioral and metabolic approaches to treating obesity should also be developed.

\section{CONCLUSION}

Several studies have shown that oxytocin reduced food consumption, increased energy consumption, and caused weight loss in animals and humans. Oxytocin reduced the consumption of appetizing foods such as fats and carbohydrates, resulting in weight loss. Oxytocin was also shown to affect the metabolism of glucose and lipids in humans. These effects can result in weight loss through homeostatic pathways, reward processing, and cognitive control, especially in obese patients. ${ }^{96}$ The administration of oxytocin had a positive effect on excessive appetite by producing satiety and reducing visceral fat. Thus, we suggest that oxytocin may be a beneficial new treatment option for obesity.

\section{CONFLICTS OF INTEREST}

The authors declare no conflict of interest.

\section{ACKNOWLEDGMENTS}

This research was supported by a grant from the Korea Health Technology R\&D Project through the Korea Health Industry Development Institute (KHIDI), funded by the Ministry of Health \& Welfare, Republic of Korea (grant no. HI18C0956).

\section{AUTHOR CONTRIBUTIONS}

Study concept and design: YRK; acquisition of data: all authors; drafting of the manuscript: all authors; critical revision of the manuscript: SMH and YRK; obtained funding: YRK; administrative, technical, or material support: YRK; and study supervision: YRK.

\section{REFERENCES}

1. Lawson EA. The effects of oxytocin on eating behaviour and metabolism in humans. Nat Rev Endocrinol 2017;13:700-9.
2. Ferguson JN, Young LJ, Hearn EF, Matzuk MM, Insel TR, Winslow JT. Social amnesia in mice lacking the oxytocin gene. Nat Genet 2000;25:284-8.

3. Jørgensen H, Knigge U, Kjaer A, Warberg J. Serotonergic involvement in stress-induced vasopressin and oxytocin secretion. Eur J Endocrinol 2002;147:815-24.

4. Tribollet E, Barberis C, Dubois-Dauphin M, Dreifuss JJ. Localization and characterization of binding sites for vasopressin and oxytocin in the brain of the guinea pig. Brain Res 1992; 589:15-23.

5. Sabatier N, Rowe I, Leng G. Central release of oxytocin and the ventromedial hypothalamus. Biochem Soc Trans 2007; 35(Pt 5):1247-51.

6. Veening JG, de Jong T, Barendregt HP. Oxytocin-messages via the cerebrospinal fluid: behavioral effects: a review. Physiol Behav 2010;101:193-210.

7. Ohlsson B, Truedsson M, Djerf P, Sundler F. Oxytocin is expressed throughout the human gastrointestinal tract. Regul Pept 2006;135:7-11.

8. Kang YS, Park JH. Brain uptake and the analgesic effect of oxytocin: its usefulness as an analgesic agent. Arch Pharm Res 2000;23:391-5.

9. Welch MG, Tamir H, Gross KJ, Chen J, Anwar M, Gershon MD. Expression and developmental regulation of oxytocin (OT) and oxytocin receptors (OTR) in the enteric nervous system (ENS) and intestinal epithelium. J Comp Neurol 2009; 512:256-70.

10. Ho JM, Anekonda VT, Thompson BW, Zhu M, Curry RW, Hwang $\mathrm{BH}$, et al. Hindbrain oxytocin receptors contribute to the effects of circulating oxytocin on food intake in male rats. Endocrinology 2014;155:2845-57.

11. Blevins JE, Graham JL, Morton GJ, Bales KL, Schwartz MW, Baskin DG, et al. Chronic oxytocin administration inhibits food intake, increases energy expenditure, and produces weight loss in fructose-fed obese rhesus monkeys. Am J Physiol Regul Integr Comp Physiol 2015;308:R431-8.

12. Iwasaki Y, Maejima Y, Suyama S, Yoshida M, Arai T, Katsurada $\mathrm{K}$, et al. Peripheral oxytocin activates vagal afferent neurons to suppress feeding in normal and leptin-resistant mice: a route for ameliorating hyperphagia and obesity. Am J Physiol 
Regul Integr Comp Physiol 2015;308:R360-9.

13. Poulain DA, Wakerley JB. Electrophysiology of hypothalamic magnocellular neurones secreting oxytocin and vasopressin. Neuroscience 1982;7:773-808.

14. Olszewski PK, Klockars A, Levine AS. Oxytocin: a conditional anorexigen whose effects on appetite depend on the physiological, behavioural and social contexts. J Neuroendocrinol 2016;28.

15. Sabatier N, Leng G, Menzies J. Oxytocin, feeding, and satiety. Front Endocrinol (Lausanne) 2013;4:35.

16. Spetter MS, Hallschmid M. Current findings on the role of oxytocin in the regulation of food intake. Physiol Behav 2017; 176:31-9.

17. Swanson LW, Kuypers HG. The paraventricular nucleus of the hypothalamus: cytoarchitectonic subdivisions and organization of projections to the pituitary, dorsal vagal complex, and spinal cord as demonstrated by retrograde fluorescence double-labeling methods. J Comp Neurol 1980;194:555-70.

18. Sawchenko PE, Swanson LW. The organization of noradrenergic pathways from the brainstem to the paraventricular and supraoptic nuclei in the rat. Brain Res 1982;257:275-325.

19. Gimpl G, Fahrenholz F. The oxytocin receptor system: structure, function, and regulation. Physiol Rev 2001;81:629-83.

20. Boccia ML, Petrusz P, Suzuki K, Marson L, Pedersen CA. Immunohistochemical localization of oxytocin receptors in human brain. Neuroscience 2013;253:155-64.

21. Melis MR, Argiolas A. Central control of penile erection: a re-visitation of the role of oxytocin and its interaction with dopamine and glutamic acid in male rats. Neurosci Biobehav Rev 2011;35:939-55.

22. Melis MR, Succu S, Sanna F, Boi A, Argiolas A. Oxytocin injected into the ventral subiculum or the posteromedial cortical nucleus of the amygdala induces penile erection and increases extracellular dopamine levels in the nucleus accumbens of male rats. Eur J Neurosci 2009;30:1349-57.

23. Denda S, Takei K, Kumamoto J, Goto M, Tsutsumi M, Denda M. Oxytocin is expressed in epidermal keratinocytes and released upon stimulation with adenosine 5 - $[\gamma$-thio $]$ triphosphate in vitro. Exp Dermatol 2012;21:535-7.

24. Jankowski M, Wang D, Hajjar F, Mukaddam-Daher S, McCann
SM, Gutkowska J. Oxytocin and its receptors are synthesized in the rat vasculature. Proc Natl Acad Sci U S A 2000;97: 6207-11.

25. Kiss A, Mikkelsen JD. Oxytocin: anatomy and functional assignments: a minireview. Endocr Regul 2005;39:97-105.

26. Chaves VE, Frasson D, Kawashita NH. Several agents and pathways regulate lipolysis in adipocytes. Biochimie 2011;93: $1631-40$

27. Danalache BA, Gutkowska J, Slusarz MJ, Berezowska I, Jankowski M. Oxytocin-Gly-Lys-Arg: a novel cardiomyogenic peptide. PLoS One 2010;5:e13643.

28. Stoop R. Neuromodulation by oxytocin and vasopressin. Neuron $2012 ; 76: 142-59$.

29. Egan JJ, Saltis J, Wek SA, Simpson IA, Londos C. Insulin, oxytocin, and vasopressin stimulate protein kinase $\mathrm{C}$ activity in adipocyte plasma membranes. Proc Natl Acad Sci U S A 1990; 87:1052-6.

30. Qin J, Feng M, Wang C, Ye Y, Wang PS, Liu C. Oxytocin receptor expressed on the smooth muscle mediates the excitatory effect of oxytocin on gastric motility in rats. Neurogastroenterol Motil 2009;21:430-8.

31. Feng M, Qin J, Wang C, Ye Y, Wang S, Xie D, et al. Estradiol upregulates the expression of oxytocin receptor in colon in rats. Am J Physiol Endocrinol Metab 2009;296:E1059-66.

32. Zhang G, Cai D. Circadian intervention of obesity development via resting-stage feeding manipulation or oxytocin treatment. Am J Physiol Endocrinol Metab 2011;301:E1004-12.

33. Deblon N, Veyrat-Durebex C, Bourgoin L, Caillon A, Bussier AL, Petrosino S, et al. Mechanisms of the anti-obesity effects of oxytocin in diet-induced obese rats. PLoS One 2011;6: e25565.

34. Blevins JE, Baskin DG. Translational and therapeutic potential of oxytocin as an anti-obesity strategy: insights from rodents, nonhuman primates and humans. Physiol Behav 2015; 152(Pt B):438-49.

35. Gould BR, Zingg HH. Mapping oxytocin receptor gene expression in the mouse brain and mammary gland using an oxytocin receptor-LacZ reporter mouse. Neuroscience 2003; 122:155-67.

36. Yoshida M, Takayanagi Y, Inoue K, Kimura T, Young LJ, On- 
aka T, et al. Evidence that oxytocin exerts anxiolytic effects via oxytocin receptor expressed in serotonergic neurons in mice. J Neurosci 2009;29:2259-71.

37. Hidema S, Fukuda T, Hiraoka Y, Mizukami H, Hayashi R, Otsuka A, et al. Generation of Oxtr cDNA(HA)-Ires-Cre mice for gene expression in an oxytocin receptor specific manner. J Cell Biochem 2016;117:1099-111.

38. Peris J, MacFadyen K, Smith JA, de Kloet AD, Wang L, Krause EG. Oxytocin receptors are expressed on dopamine and glutamate neurons in the mouse ventral tegmental area that project to nucleus accumbens and other mesolimbic targets. J Comp Neurol 2017;525:1094-108.

39. Altirriba J, Poher AL, Caillon A, Arsenijevic D, Veyrat-Durebex $\mathrm{C}$, Lyautey J, et al. Divergent effects of oxytocin treatment of obese diabetic mice on adiposity and diabetes. Endocrinology 2014;155:4189-201.

40. Gajdosechova L, Krskova K, Segarra AB, Spolcova A, Suski M, Olszanecki R, et al. Hypooxytocinaemia in obese Zucker rats relates to oxytocin degradation in liver and adipose tissue. J Endocrinol 2014;220:333-43.

41. Muchmore DB, Little SA, de Haën C. A dual mechanism of action of ocytocin in rat epididymal fat cells. J Biol Chem 1981;256:365-72.

42. Suzuki M, Honda Y, Li MZ, Masuko S, Murata Y. The localization of oxytocin receptors in the islets of Langerhans in the rat pancreas. Regul Pept 2013;183:42-5.

43. Antoni FA. Oxytocin receptors in rat adenohypophysis: evidence from radioligand binding studies. Endocrinology 1986; 119:2393-5.

44. Chaves VE, Tilelli CQ, Brito NA, Brito MN. Role of oxytocin in energy metabolism. Peptides 2013;45:9-14.

45. Wheeler E, Huang N, Bochukova EG, Keogh JM, Lindsay S, Garg S, et al. Genome-wide SNP and CNV analysis identifies common and low-frequency variants associated with severe early-onset obesity. Nat Genet 2013;45:513-7.

46. Schorr M, Marengi DA, Pulumo RL, Yu E, Eddy KT, Klibanski A, et al. Oxytocin and its relationship to body composition, bone mineral density, and hip geometry across the weight spectrum. J Clin Endocrinol Metab 2017;102:2814-24.

47. Stock S, Granström L, Backman L, Matthiesen AS, Uvnäs-
Moberg K. Elevated plasma levels of oxytocin in obese subjects before and after gastric banding. Int J Obes 1989;13:213-22.

48. Szulc P, Amri EZ, Varennes A, Panaia-Ferrari P, Fontas E, Goudable J, et al. High serum oxytocin is associated with metabolic syndrome in older men: the MINOS study. Diabetes Res Clin Pract 2016;122:17-27.

49. Maejima Y, Iwasaki Y, Yamahara Y, Kodaira M, Sedbazar U, Yada T. Peripheral oxytocin treatment ameliorates obesity by reducing food intake and visceral fat mass. Aging (Albany NY) 2011;3:1169-77.

50. Blevins JE, Thompson BW, Anekonda VT, Ho JM, Graham JL, Roberts ZS, et al. Chronic CNS oxytocin signaling preferentially induces fat loss in high-fat diet-fed rats by enhancing satiety responses and increasing lipid utilization. Am J Physiol Regul Integr Comp Physiol 2016;310:R640-58.

51. Pischon T, Boeing H, Hoffmann K, Bergmann M, Schulze $\mathrm{MB}$, Overvad $\mathrm{K}$, et al. General and abdominal adiposity and risk of death in Europe. N Engl J Med 2008;359:2105-20.

52. Alberi S, Dreifuss JJ, Raggenbass M. The oxytocin-induced inward current in vagal neurons of the rat is mediated by $\mathrm{G}$ protein activation but not by an increase in the intracellular calcium concentration. Eur J Neurosci 1997;9:2605-12.

53. Kasahara Y, Takayanagi Y, Kawada T, Itoi K, Nishimori K. Impaired thermoregulatory ability of oxytocin-deficient mice during cold-exposure. Biosci Biotechnol Biochem 2007;71: 3122-6.

54. Lawson EA, Marengi DA, DeSanti RL, Holmes TM, Schoenfeld DA, Tolley CJ. Oxytocin reduces caloric intake in men. Obesity (Silver Spring) 2015;23:950-6.

55. Bathgate RA, Sernia C. Characterization of vasopressin and oxytocin receptors in an Australian marsupial. J Endocrinol 1995;144:19-29.

56. Heinrichs M, Baumgartner T, Kirschbaum C, Ehlert U. Social support and oxytocin interact to suppress cortisol and subjective responses to psychosocial stress. Biol Psychiatry 2003;54: 1389-98.

57. Legros JJ, Chiodera P, Demey-Ponsart E. Inhibitory influence of exogenous oxytocin on adrenocorticotropin secretion in normal human subjects. J Clin Endocrinol Metab 1982;55: 1035-9. 
58. Legros JJ, Chiodera P, Geenen V, Smitz S, von Frenckell R. Dose-response relationship between plasma oxytocin and cortisol and adrenocorticotropin concentrations during oxytocin infusion in normal men. J Clin Endocrinol Metab 1984; 58:105-9.

59. Linnen AM, Ellenbogen MA, Cardoso C, Joober R. Intranasal oxytocin and salivary cortisol concentrations during social rejection in university students. Stress 2012;15:393-402.

60. Cardoso C, Kingdon D, Ellenbogen MA. A meta-analytic review of the impact of intranasal oxytocin administration on cortisol concentrations during laboratory tasks: moderation by method and mental health. Psychoneuroendocrinology 2014;49:161-70

61. Burt RL, Leake NH, Dannenburg WN. Effect of synthetic oxytocin on plasma nonesterified fatty acids, triglycerides, and blood glucose. Obstet Gynecol 1963;21:708-12.

62. Spellacy WN, Carlson KL, Birk SA. Effect of posterior pituitary hormones on blood glucose and plasma insulin levels in postpartum patients. Obstet Gynecol 1966;28:355-9.

63. Chiodera P, Coiro V, Camellini L, Rossi G, Pignatti D, Volpi R, et al. Effect of pharmacological doses of oxytocin on insulin response to glucose in normal man. Horm Res 1984;20:150-4.

64. Paolisso G, Sgambato S, Passariello N, Torella R, Giugliano D, Mignano S, et al. Pharmacological doses of oxytocin affect plasma hormone levels modulating glucose homeostasis in normal man. Horm Res 1988;30:10-6.

65. Klement J, Ott V, Rapp K, Brede S, Piccinini F, Cobelli C, et al. Oxytocin improves $\beta$-Cell responsivity and glucose tolerance in healthy men. Diabetes 2017;66:264-71.

66. Qian W, Zhu T, Tang B, Yu S, Hu H, Sun W, et al. Decreased circulating levels of oxytocin in obesity and newly diagnosed type 2 diabetic patients. J Clin Endocrinol Metab 2014;99: 4683-9.

67. Kujath AS, Quinn L, Elliott ME, Varady KA, LeCaire TJ, Carter CS, et al. Oxytocin levels are lower in premenopausal women with type 1 diabetes mellitus compared with matched controls. Diabetes Metab Res Rev 2015;31:102-12.

68. Eckertova M, Ondrejcakova M, Krskova K, Zorad S, Jezova D. Subchronic treatment of rats with oxytocin results in improved adipocyte differentiation and increased gene expression of factors involved in adipogenesis. Br J Pharmacol 2011;162: $452-63$.

69. Björkstrand E, Eriksson M, Uvnäs-Moberg K. Evidence of a peripheral and a central effect of oxytocin on pancreatic hormone release in rats. Neuroendocrinology 1996;63:377-83.

70. Gao ZY, Drews G, Henquin JC. Mechanisms of the stimulation of insulin release by oxytocin in normal mouse islets. Biochem J 1991;276 ( Pt 1):169-74.

71. Sclafani A, Rinaman L, Vollmer RR, Amico JA. Oxytocin knockout mice demonstrate enhanced intake of sweet and nonsweet carbohydrate solutions. Am J Physiol Regul Integr Comp Physiol 2007;292:R1828-33.

72. Miedlar JA, Rinaman L, Vollmer RR, Amico JA. Oxytocin gene deletion mice overconsume palatable sucrose solution but not palatable lipid emulsions. Am J Physiol Regul Integr Comp Physiol 2007;293:R1063-8.

73. Amico JA, Vollmer RR, Cai HM, Miedlar JA, Rinaman L. Enhanced initial and sustained intake of sucrose solution in mice with an oxytocin gene deletion. Am J Physiol Regul Integr Comp Physiol 2005;289:R1798-806.

74. Takayanagi Y, Kasahara Y, Onaka T, Takahashi N, Kawada T, Nishimori K. Oxytocin receptor-deficient mice developed late-onset obesity. Neuroreport 2008;19:951-5.

75. Olszewski PK, Klockars A, Olszewska AM, Fredriksson R, Schiöth HB, Levine AS. Molecular, immunohistochemical, and pharmacological evidence of oxytocin's role as inhibitor of carbohydrate but not fat intake. Endocrinology 2010;151: 4736-44.

76. Mitra A, Gosnell BA, Schiöth HB, Grace MK, Klockars A, Olszewski PK, et al. Chronic sugar intake dampens feedingrelated activity of neurons synthesizing a satiety mediator, oxytocin. Peptides 2010;31:1346-52.

77. Kublaoui BM, Gemelli T, Tolson KP, Wang Y, Zinn AR. Oxytocin deficiency mediates hyperphagic obesity of Sim1 haploinsufficient mice. Mol Endocrinol 2008;22:1723-34.

78. Wu Z, Xu Y, Zhu Y, Sutton AK, Zhao R, Lowell BB, et al. An obligate role of oxytocin neurons in diet induced energy expenditure. PLoS One 2012;7:e45167.

79. Zhang G, Bai H, Zhang H, Dean C, Wu Q, Li J, et al. Neuropeptide exocytosis involving synaptotagmin-4 and oxytocin 
in hypothalamic programming of body weight and energy balance. Neuron 2011;69:523-35.

80. Arletti R, Benelli A, Bertolini A. Oxytocin inhibits food and fluid intake in rats. Physiol Behav 1990;48:825-30.

81. Morton GJ, Thatcher BS, Reidelberger RD, Ogimoto K, WoldenHanson T, Baskin DG, et al. Peripheral oxytocin suppresses food intake and causes weight loss in diet-induced obese rats. Am J Physiol Endocrinol Metab 2012;302:E134-44.

82. Benelli A, Bertolini A, Arletti R. Oxytocin-induced inhibition of feeding and drinking: no sexual dimorphism in rats. Neuropeptides 1991;20:57-62.

83. Leslie M, Silva P, Paloyelis Y, Blevins J, Treasure J. A systematic review and quantitative meta-analysis of Oxytocin's effects on feeding. J Neuroendocrinol 2018;30:e12584.

84. Holder JL Jr, Butte NF, Zinn AR. Profound obesity associated with a balanced translocation that disrupts the SIM1 gene. Hum Mol Genet 2000;9:101-8.

85. Ramachandrappa S, Raimondo A, Cali AM, Keogh JM, Henning E, Saeed S, et al. Rare variants in single-minded 1 (SIM1) are associated with severe obesity. J Clin Invest 2013;123: 3042-50.

86. Swaab DF, Purba JS, Hofman MA. Alterations in the hypothalamic paraventricular nucleus and its oxytocin neurons (putative satiety cells) in Prader-Willi syndrome: a study of five cases. J Clin Endocrinol Metab 1995;80:573-9.

87. Spetter MS, Feld GB, Thienel M, Preissl H, Hege MA, Hallschmid M. Oxytocin curbs calorie intake via food-specific increases in the activity of brain areas that process reward and establish cognitive control. Sci Rep 2018;8:2736.
88. Kim YR, Eom JS, Yang JW, Kang J, Treasure J. The impact of oxytocin on food intake and emotion recognition in patients with eating disorders: a double blind single dose within-subject cross-over design. PLoS One 2015;10:e0137514.

89. Ott V, Finlayson G, Lehnert H, Heitmann B, Heinrichs M, Born J, et al. Oxytocin reduces reward-driven food intake in humans. Diabetes 2013;62:3418-25.

90. Thienel M, Fritsche A, Heinrichs M, Peter A, Ewers M, Lehnert $\mathrm{H}$, et al. Oxytocin's inhibitory effect on food intake is stronger in obese than normal-weight men. Int J Obes (Lond) 2016; 40:1707-14.

91. Zhang H, Wu C, Chen Q, Chen X, Xu Z, Wu J, et al. Treatment of obesity and diabetes using oxytocin or analogs in patients and mouse models. PLoS One 2013;8:e61477.

92. Turton R, Chami R, Treasure J. Emotional eating, binge eating and animal models of binge-type eating disorders. Curr Obes Rep 2017;6:217-28.

93. MacDonald E, Dadds MR, Brennan JL, Williams K, Levy F, Cauchi AJ. A review of safety, side-effects and subjective reactions to intranasal oxytocin in human research. Psychoneuroendocrinology 2011;36:1114-26.

94. Petersson M. Cardiovascular effects of oxytocin. Prog Brain Res 2002;139:281-8.

95. Rasmussen MS, Simonsen JA, Sandgaard NC, Høilund-Carlsen PF, Bie P. Effects of oxytocin in normal man during low and high sodium diets. Acta Physiol Scand 2004;181:247-57.

96. Plessow F, Eddy KT, Lawson EA. The neuropeptide hormone oxytocin in eating disorders. Curr Psychiatry Rep 2018;20:91. 